\title{
MELATIH METAKOGNISI SISWA DALAM MENUMBUH KEMBANGKAN EFIKASI DIRI (SELF-EFFICACY PADA PEMBELAJARAN MATEMATIKA
}

\author{
N. ERNI SUSIANI \\ MAN 2 Kota Bekasi \\ Email : ernisusiani93@gmail.com
}

\begin{abstract}
This study aims to find out how to train students' metacognition in developing self-efficacy in the Mathematics subject matter. The writing of this article uses a library research approach or literature study literature. Metacognition in general relates to how to explore one's thoughts about thinking. Self-efficacy is a form of belief or belief related to one's own ability to organize, do something to achieve a goal, produce something, and also implement actions in order to achieve a certain form of skill. Based on the literature study, training students' metacognition in developing self-efficacy in learning mathematics includes two dimensions of thinking, namely the awareness that a person has about his or her thinking (self-awareness of cognition) and a person's ability to use his/her consciousness to regulate his thinking process (selfregulation of cognition). By training to develop students' metacognitive awareness, it is expected that students can organize the information they face in solving problem-based questions so that they can develop students' mathematical self-efficacy.
\end{abstract}

\begin{abstract}
ABSTRAK
Penelitian ini bertujuan untuk Mengetahui bagaimana cara melatih metakognisi siswa dalam menumbuhkembangkan efikasi diri pada mata pelajaran Matematika. Penulisan artikel ini dengan mengunakan pendekatan Library research atau kepustakaan Study Literatur. Metakognisi secara umum berkaitan dengan bagaimana menggali pemikiran seseorang tentang berpikir. Efikasi diri adalah suatu bentuk kepercayaan atau keyakinan terkait kemampuan dirinya sendiri dalam mengatur, melakukan sesuatu guna mencapai suatu tujuan, menghasilkan sesuatu, dan juga mengimplementasikan tindakan agar bisa mencapai suatu bentuk kecakapan tertentu. Berdasarkan Study literatur melatih Metakognisi siswa dalam menumbuh kembangkan Efikasi diri pada pembelajaran matematika meliputi dua dimensi berpikir yaitu kesadaran yang dimiliki seseorang tentang berpikirnya (selfawareness of cognition) dan kemampuan seseorang menggunakan kesadarannya untuk mengatur proses berpikirnya (self-regulation of cognition). Dengan melatih mengembangkan kesadaran metakognisi siwa diharapkan siswa dapat mengorganisasi informasi yang dihadapi dalam menyelesaiakan soal-soal berbasis masalah sehingga dapat menumbuh kembangkan efikasi diri matematis siswa.

Kata kunci : Efikasi diri Metakognisi, Efikasi diri, pembelajaran matematika.
\end{abstract}

\section{PENDAHULUAN}

Matematika adalah pelajaran yang menuntut bakat dan kemampuan alamiah sehingga tidak semua orang mampu mengatasinya. Siswa pada jenjang SMA memasuki tahapan remaja dimana pada tahapan ini seorang remaja dituntut untuk dapat membuktikan kemampuan dan eksistensi dirinya kepada lingkungannya. Setiap remaja akan berusaha untuk dapat membuktikan dirinya sebagai individu yang mampu mengatasi tugas dan permasalahannya agar dapat eksis di hadapan lingkungannya terutama di depan teman temannya.

Proses belajar mengajar matematika berhubungan dengan banyak konsep. Konsep matematika memiliki hubungan antara satu konsep dengan konsep lainnya. Banyak dari kalangan siswa merasa matematika adalah pelajaran yang rumit untuk dipelajari karena sifatnya yang abstrak, berhubungan dengan banyak konsep dan memiliki hubungan antara satu konsep dengan konsep lainnya. Konsep matematika yang abstrak tersusun secara berurutan dan berjenjang serta diperlukan pembuktian khusus, sehingga dalam proses pembelajaran konsep 
matematika sebelumnya harus dikuasai karena merupakan prasyarat untuk melanjutkan konsep berikutnya (Misel, 2016; Sudianto, 2017).

Kurangnya kemampuan pemahaman konsep matematika yang di bawa dari jenjang kelas sebelumnya atau kemampuan awal akan berdampak pada proses pembelajaran matematika di kelas, hal ini merupakan salah satu problem bagi guru untuk mengulang kembali materi yang menjadi prasyarat pada materi yang akan diajarkan. Situasi seperti ini akan menggangu waktu yang digunakan pada pokok bahasan baru yang akan disampaikan sehingga tidak lagi sesuai dengan rencana program pembelajaran yang sudah dibuat sebelumnya.

Selanjutnya, kurangnya penguasaaan metode, pendekatan pembelajaran serta pengunaan media ajar yang sesuai dengan materi matematika di setiap jenjang kelas merupakan problematika pembelajaran matematika yang disebabkan oleh faktor guru. hal ini menyebabkan siswa kesulitan memahami materi matematika, apalagi tidak semua materi matematika dapat menggunakan media pembelajaran yang konkrit.

Baik permasalahan yang disebabkan dari guru maupun siswa, menyebabkan siswa tidak mampu menunjukkan prestasi akademisnya secara optimal sesuai dengan kemampuan yang dimilikinya. Salah satu penyebabnya adalah karena mereka sering merasa tidak yakin bahwa dirinya akan mampu menyelesaikan tugas-tugas yang dibebankan kepadanya. sebagian besar siswa merasa kurang memiliki pengharapan atau keyakinan yang sebenarnya merupakan indikator efikasi diri yang kurang baik terhadap pelajaran matematika di sekolah

Bagi siswa, keyakinan seperti ini sangat diperlukan, keyakinan yang didasari oleh batas-batas kemampuan yang dirasakan akan menuntun siswa mampu menyelesaikan tugas tugas yang diberikan guru. Istilah keyakinan ini yang disebut efikasi diri (self efficacy). Efikasi diri secara numum merupakan keyakinan seseorang mengenai kemampuannya dalam mengatasi beraneka ragam situasi yang muncul dalam hidupnya dan tidak terkait dengan kecakapan yang dimiliki melainkan dengan keyakinan individu mengenai hal yang dapat dilakukan dengan kecakapan yang ia miliki.

Salah satu faktor internal non kognitif yang berpengaruh besar terhadap prestasi belajar matematika di setiap jenjang pendidikan sangatlah penting dalam membantu memahami proses berpikir matematis, efikasi diri juga merupakan salah satu variabel penting dalam self-regulate learning dan mempengaruhi fungsi kognisi (aktivitas berpikir), afeksi (perasaan) dan konasi (aktivitas psikis) siswa.

Efikasi diri tidak berkaitan langsung dengan kecakapan yang dimiliki individu, melainkan tentang penilaian diri dari apa yang dapat dilakukan, tanpa terkait dengan kecakapan yang dimiliki. Konsep dasar teori efikasi diri (self efficacy) adalah keyakinan bahwa pada setiap individu mempunyai kemampuan mengontrol pikiran, perasaan dan perilakunya. Efikasi diri merupakan masalah persepsi subyektif, yang berarti efikasi diri tidak menggambarkan kemampuan yang sebenarnya, tetapi terkait dengan keyakinan yang dimiliki individual.

Pembelajaran yang dapat menumbuh kembangkan efikasi diri pada pembelajaran matematika yaitu pembelajaran yang bisa melatih metakognisi siswa. Dimana, siswa dapat menilai kesukaran sesuatu masalah, kemampuan untuk mengamati kesadaran seseorang tentang bagaimana ia belajar, kemampuan untuk tingkat pemahaman dirinya, kemampuan menggunakan berbagai informasi untuk mencapai tujuan, dan kemampuan menilai kemajuan belajar sendiri. Strategi metakognitif tersebut hanya merupakan salah satu dari strategi-strategi pembelajaran lainnya yang dapat menumbuhkan self efficacy matematis siswa melalui pembelajaran berbasis masalah.

Menurut (Arrend: 41: 2007) model pembelajaran berdasarkan masalah adalah model pembelajaran siswa terkait dengan masalah-masalah autentik dan bermakna bagi siswa sehingga siswa dapat menyusun pengetahuannya sendiri, menumbuh kembangkan keterampilan berpikir kritis dan menyelesaikan masalah, serta mendapatkan pengetahuan konsep konsep penting. konsep pembelajaran ini mengutamalan proses belajar yang memfokuskan guru untuk membantu siswa mencapai keterampilan mengarahkan diri siswa, melatih siswa untuk berfikir logis dan analitis sesuai dengan tujuan pembelajaran matematika 
menurut Kemendikbud tahun 2013 adalah membentuk kemampuan siswa dalam menyelesaikan suatu masalah secara sistematis.

Agar terwujudnya tujuan pembelajaran matematika berbasis masalah tersebut dibutuhkan peran guru dalam mengembangkan kemampuan metakognisi siswa terutama mengatur dan mengontrol proses-proses kognitif dalam belajar dan berpikir siswa sehingga cara belajar dan berpikir siswa lebih terarah. hal ini sesuai dengn konsep metakognisi secara umum yang berkaitan dengan bagaimana menggali pemikiran seseorang tentang berpikir.

Dengan melatih kesadaran metakognisi, siswa mampu merancang strategi terbaik dalam menyelesaikan masalah sehingga efikasi diri yaitu kepercayaan pada kemampuan diri dalam mengatur dan melaksanakan suatu tindakan yang diperlukan dalam rangka pencapaian hasil usaha dapat meningkat

\section{METODE PENELITIAN}

Penelitian ini merupakan penelitian kualitatif dengan teknik analisis deskriptif dengan kajian kepustakaan (library Research), Studi kepustakaan ialah serangkaian kegiatan yang berkenaan dengan metode pengumpulan data pustaka, membaca dan mencatat serta mengolah bahan penelitian (Mestika Zed, 2008, h. 3). Studi kepustakaan juga merupakan kajian teoritis, referensi serta literatur ilmiah lainnya yang berkaitan dengan budaya, nilai dan norma yang berkembang pada situasi. Penelitian kualitatif dengan teknik analisa deskriptif kajian kepustakaan dengan menelaah jurnal terkait mengenai bagaimana melatih mengembangkan metakognisi sebagai salah satu strategi untuk meningkatkan efikasi diri pada pembelajaran matematika serta peran guru dalam mengembangkan metakognisidalam pembelajaran matematika.

\section{HASIL DAN PEMBAHASAN}

\section{Pembelajaran matematika}

Mata pelajaran matematika selain bidang ilmu yang mempelajari banyak hal yang berkaitan dengan kehidupan manusia sehari-hari juga mempunyai peranan penting dalam kemajuan ilmu pengetahuan. matematika dianggap perlu dipelajari di semua jenjang sehingga menjadi mata pelajaran pokok terutama di jurusan IPA. mata pelajaran matematika dianggap perlu di pelajari karena matematika merupakan sarana berfikir untuk menumbuhkembangkan pola berfikir kritis, sistematis, objektif, dan rasional.

Glaser mendefinisikan berpikir kritis sebagai suatu sikap berpikir secara mendalam terkait masalah- masalah dan hal-hal yang berada dalam jangkauan pengalaman seseorang (Fisher, 2008: h.3). Selanjutnya (Soedjadi, 2000, 11) menjelaskan beberapa definisi tentang matematika, yaitu: (1) Matematika adalah cabang ilmu pengetahuan eksak dan terorganisir secara sistematik. (2) Matematika adalah pengetahuan tentang bilangan kalkulasi. (3) Matematika adalah pengetahuan tentang penalaran logika dan berhubungan dengan bilanganbilangan. (4) Matematika adalah pengetahuan tentang fakta-fakta kuantitatif dan masalahmasalah tentang ruang dan bentuk. (5 ) Matematika adalah pengetahuan tentang struktur yang logik. (6) Matematika adalah pengetahuan tentang aturan-aturan yang ketat.

Pada hakekatnya mempelajari matematika adalah mempelajari ide-ide abstrak yang diberi simbol-simbol yang perlu diketahui tentang pemahaman konsep. Belajar akan bermakna bagi siswa apabila mereka aktif dengan berbagai cara untuk mengkonstruksi atau membangun sendiri pengetahuannya. Dengan demikian, suatu rumus, konsep, atau prinsip dalam matematika, seyogyanya ditemukan kembali oleh pebelajar di bawah bimbingan guru.

Pembelajaran yang mengkondisikan siswa untuk menemukan kembali akan membiasakan siswa untuk melakukan penyelidikan dan menemukan sesuatu. Secara khusus, pendekatan pemecahan masalah merupakan fokus dalam pembelajaran matematika yang sesuain dengan kompetensi dasar yang diharapkan. Ditinjau dari aspek kompetensi yang ingin dicapai, mata pelajaran matematika menekankan penguasaan konsep dan algoritma di samping keterampilan memecahkan masalah 


\section{Efikasi Diri dalam Pembelajaran Matematika}

Efikasi diri adalah penilaian seseorang mengenai kemampuan diri sendiri untuk mengerjakan suatu tugas atau mencapai tujuan yang diinginkan (Ormrod, 2009, h. 20). Efikasi diri merupakan suatu keyakinan pribadi bahwa dia mampu untuk menyelesaikan serangkaian tugas spesifik, Maksudnya adalah keyakinan sesorang terhadap kemampuan atau kecakapannya. (Bandura,1997, h. 2). dalam bagian lain (Bandura,1986, h.391) menyatakan Efikasi diri adalah, "the beliefs in one's capabilities to organize and execute the courses of action required to manage prospective situasions.sebagai "people's judgement of their capabilities to organize and execute courses of action requared to attain designated types of performances. artinya adalah keyakinan sesorang akan kemampuannya mengorganisasikan dan melakukan tindakan-tindakan yang perlu dalam mencapai tingkat kinerja tertentu, yang mempengaruhi tingkat pencapaian tugasnya. Efikasi diri merupakan konsep yang diturunkan dari Teori Kognitif Sosial (Sosial-Cognitive Theory) yang digagas oleh Albert Bandura.Teori ini memandang pembelajaran sebagai penguasaan pengetahuan melalui pemrosesan secara kognitif informasi yang diterima. Istilah "sosial" mengandung pengertian bahwa pemikiran dan kegiatan manusia berawal dari apa yang dipelajari dalam masyarakat, sedangkan istilah "kognitif" mengandung pengertian bahwa terdapat kontribusi influensial proses kognitif terhadap motivasi, sikap, dan perilaku manusia.

Secara singkat, teori ini menyatakan bahwa sebagian besar pengetahuan dan perilaku anggota organisasi digerakkan dari lingkungan, dan secara terus-menerus mengalami proses berpikir terhadap informasi yang diterima. Selain itu, proses ini pada setiap individu berbeda dengan individu lainnya, bergantung pada keunikan karateristik personalnya. Berdasarkan pendapat diatas, diketahui bahwa keyakinan diri adalah representasi mental dan kognitif individu atas realitas, yang terbentuk oleh pengalaman-pengalaman masa lalu dan masa kini, dan disimpan dalam memori. Dalam jangka panjang keyakinan ini mempengaruhi cara-cara sosialisasi yang akan dilakukan serta cara pandang seseorang terhadap kualitas dirinya sendiri, yang baik atau yang buruk. Dengan demikian efikasi diri menentukan besarnya usaha atau keuletan yang dilakukan seseorang dalam menghadapi tugas atau kegiatan.

Berdasarkan uraian di atas efikasi diri merupakn keyakinan seseorang mengenai kemampuannya dalam mengatasi berbagai situasi yang muncul dalam hidupnya. Efikasi diri dapat mempengaruhi bagaimana cara seseorang bertindak dan mencapai hasil hasil yang maksimal. Salah satu faktor internal non kognitif yang berpengaruh besar terhadap prestasi belajar matematika adalah efikasi diri, peningkatan efikasi diri matematika dalam proses pembelajaran matematika di setip jenjang pendidikan sangat penting. Efikasi diri akan mempengaruhi beberapa aspek kognisi dan prilaku seseorang. Oleh karena itu, prilaku satu individu akan berbeda dengan individu lain.

Sebuah meta analisis yang ditulis oleh [1] M. Nur Ghufron dan Rini Risnawita Suminta menjelaskan bahwa Pajares dan Kranzler (1995) menemukan pengaruh efikasi diri pada kinerja matematika sekuat pengaruh kemampuan mental secara umum. Di tingkat kemampuan, siswa memiliki efikassi diri yang lebih tinggi menunjukkan ketajaman dalam perhitungan matematika dan menunjukkan ketekunan yang lebih besar dalam pengerjaan soal soal matematika yang sulit dari pada siswa yang mempunyai efikasi yang rendah.

\section{Metakognisi}

Dalam pembelajaran matematika peserta didik dilatih secara aktif membangun pengetahuan yang dibutuhkan dari masalah yang diberikan. konsep masalah yang diberikan kepada siswa yaitu menggunakan dunia nyata sebagai suatu konteks bagi siswa untuk belajar tentang cara berpikir kritis dan keterampilan memecahkan masalah. melalui pembelajaran berbasis masalah (Problem Based Learning) siswa dapat memperoleh pengetahuan dan konsep essensial dari materi pelajaran matematika. dengan demikian, dalam pembelajaran berbasis masalah siswa dirangsang untuk berpikir tingkat tinggi dalam situasi yang berorientasi masalah artinya siswa akan belajar bagaimana belajar selain itu keterlibatan siswa dalam memecahkan 
masalah melalui tahap tahap metode ilmiah. Peran guru sebagai fasilitator perlu mengarahkan langkah-langkah dan solusi yang tepat dengan menyajikan masalah, mengajukan pertanyaan, dan memfasilitasi penyelidikan dan dialog pada saat proses pembelajaran berlangsung sehingga siswa diarahkan berpikir kritis dan kreatif.

konsep metakognisi ini adalah menggali pemikiran orang tentang berpikir "thinking about thingking". Dua dimensi berpikir menurut (Brunning, 1995, 24) meliputi dua dimensi berpikir yaitu kesadaran yang dimiliki seseorang tentang berpikirnya (selfawareness of cognition) dan kemampuan seseorang menggunakan kesadarannya untuk mengatur proses berpikirnya (self-regulation of cognition).

Flavel dalam[2] (Ummu Sholihah, 2016, 9) konsep pengetahuan metakognisi sebagai pengetahuan umum tentang bagaimana seseorang belajar dan memproses informasi, seperti pengetahuan seseorang tentang proses belajarnya sendiri. sedangkan, pengalaman metakognisi berpengaruh terhadap proses-proses kognitif yang sedang berlangsung dalam situasi yang menuntut pemikiran yang membutuhkan kesadaran meliputi pengunaaan strategi metakognitif atau regulasi metakognitif yaitu proses berurutan yang dipergunakan seseorang untuk mengontrpl aktivitas kognitifnya dan memastikan tujuan kognitif telah tercapai.

Keberhasilan siswa dalam menyelesaikan permasalahan matematis bergantung pada kesadaran siswa tentang apa yang siswa ketahui dan bagaimana siswa menerapkannya atau bermetakognisi. metakognisi memiliki peran yang sangat penting dalam mengatur dan mengontrol proses berpikir seseorang dalam belajar dan berpikir.

Menurut (Thayeb \& Putri, 2017) menyatakan bahwa metakognisi pada hakikatnya memberikan penekanan pada kesadaran berpikir seseorang tentang proses berpikirnya sendiri. Metakognisi meliputi memahami sebuah permasalahan matematis, menstrategi permasalahan matematis serta mengevaluasi permasalahan matematis. sementara, menurut Schoenfeld dalam (Widadah, Nur Afifah, \& Suroto, 2013) mendefinisikan metakognisi sebagai berikut: "metacognition is thinking about our thingking and compires of the following three important aspect: Knowledge about our own thought processes, control our selfregulation and belief and intuition". Pengertian ini menunjukkan bahwa metakognisi diartikan sebagai pemikiran tentang pemikiran kita sendiri yang merupakan interaksi antara tiga aspek pengaturan diri, serta keyakinan dan intuisi.

Selanjutnya (Jeanne Ellis Ormrod , 2008, p. 367) yang menyatakan bahwa ada beberapa hal yang merupakan proses metakognisi yaitu merefleksikan hakekat umum komponen belajar (berpikir dan ilmu pengetahuan), mengetahui batasan-batasan pembelajaran dan kapabilitas memori, mengetahui tugas-tugas belajar apa saja yang dapat dipenuhi secara realistis dalam periode tertentu, merencanakan pendekatan yang masuk akal terhadapt tugas belajar, mengetahui dan mengaplikasikan strategi strategi efektif untuk belajar dan mengingat hal baru.

kemampuan metakognitif adalah kemampuan seseorang dalam mengontrol proses belajarnya, mulai dari tahap perencanaan, memilih strategi yang tepat sesuai masalah yang dihadapi, kemudian memonitor kemajuan dalam belajar dan secara bersamaan mengoreksi jika ada kesalahan yang terjadi selama memahami konsep, menganalisis keefektifan dari strategi yang dipilih. Kemudian melakukan refleksi berupa mengubah kebiasaan belajar dan strateginya jika diperlukan, apabila hal itu dipandang tidak cocok lagi dengan kebutuhan lingkungannya.

Jadi metakognisi dikembangkan melalui proses berpikir seseorang berkenaan dengan tingkah laku yang dilakukannya. Mengembangkan metakognisi pada dasarnya adalah meningkatkan proses berpikir seseorang untuk mengontrol apa yang dipikirkannya, apa yang dikerjakannya, berkenaan dengan tugas yang diberikan, apakah telah memenuhi tuntutan yang diminta dari tugas tersebut atau belum. Kaitan antara kemampuan metakognisi dengan strategi berpikir adalah bahwa kemampuan metakognisi menyediakan cara mengarahkan dan mengendalikan berpikir yang pada akhirnya akan menghasilkan kemampuan dalam berpikir kritis (critical thingking).

Menurut (Anatahime ,2007, p. 1) indikator-indikator keterampilan metakognitif yang akan dikembangkan antara lain mengidentifikasi tugas yang sedang dikerjakan, mengawasi 
kemajuan pekerjaannya, mengevaluasi kemajuan ini, memprediksi hasil yang akan diperoleh. Keterampilan metakognisi dap digunakan untuk mengasah keterampilan berkomunikasi siswa dengan adanya indikator-indikator yang digunaka.

Peran guru dalam meningkatkan kemampuan metakognitis siswa sangatlah penting. Guru dapat bertindak sebagai fasilitator yang memberikan arahan dan bimbingan melalui pertanyaan - pertanyaan yang mengiring, mengarahkan langkah-langkah dan solusi yang tepat dengan menyajikan masalah, mengajukan pertanyaan, dan memfasilitasi penyelidikan dan dialog pada saat proses pembelajaran berlangsung sehingga siswa diarahkan berpikir kritis dan kreatif

\section{Meningkatkan Efikasi diri melalui metakognisi Pada Pembelajaran matematika}

Pembelajaran yang dapat menumbuh kembangkan efikasi diri pada pembelajaran matematika yaitu pembelajaran yang bisa melatih metakognisi siswa. Dimana, siswa dapat menilai kesukaran sesuatu masalah, kemampuan untuk mengamati kesadaran seseorang tentang bagaimana ia belajar, kemampuan untuk tingkat pemahaman dirinya, kemampuan menggunakan berbagai informasi untuk mencapai tujuan, dan kemampuan menilai kemajuan belajar sendiri. Strategi metakognitif tersebut hanya merupakan salah satu dari strategi-strategi pembelajaran lainnya yang dapat menumbuhkan efikasi diri (self efficacy) matematis siswa.

Self efficacy itu dapat dikembangkan dan dapat ditingkatkan, sehingga cara pembelajaran lainnya yang diperkirakan dapat meningkatkan Efikasi diri (self efficacy) matematis siswa adalah pembelajaran berbasis masalah. Dimana, konteks materi matematika dikaitkan dengan masalah dunia nyata bagi siswa untuk belajar tentang cara berfikir kritis dan keterampilan pemecahan masalah, serta untuk memperoleh pengetahuan dan konsep yang esensial dari materi pelajaran. Sebagaimana dikemukakan oleh Mergendoller, Maxwell, \& Belissimo (2006) menyatakan bahwa: "problem-based learning is an appealing instructional strategy. Rather than reading or hearing about the facts and concepts that define an academic field of study, students solve realistic (albeit, simulated) problems that reflect the decisions and dilemmas people face every day " artinya Pembelajaran berbasis masalah adalah strategi intruksional yang menarik, tidak sekedar membaca dan tentang fakta dan konsep yang mendefinisikan bidang study akademis, siswa memecahkan masalah yang realistis, (meskipun hanya bentuk simulasi) yang mencerminkan keputusan dan dilema yang dihadapi orang setiap hari. Tidak sekedar membaca atau mendengar tentang fakta dan konsep yang mendefinisikan bidang studi akademis, siswa memecahkan masalah yang realistis (meskipun hanya bentuk simulasi) yang mencerminkan keputusan dan dilema yang dihadapi orang setiap hari.

Keberhasilan seseorang dalam menyelesaikan maaslah tidak terlepas dari keterlibatan kemampuan kognitif seseorang. salah satu kemampuan berpikir tingkat tinggi adalah metakognisi. [2]Ummu salamah (Taallum, 2016, 15) menyatakan bahwa strategi metakognisi yang dapat dilakukan guru yaitu membangun kesadaran berpikir siswa dalam pembelajaran matematika yang di awali dengan merancang, memonitor, mengontrol dan menilai apa yang dipelajarinya atau apa yang dikerjakannya.

Adapun kaitan antara kemampuan metakognisi dengan strategi berpikir adalah bahwa kemampuan metakognisi menyediakan cara mengarahkan dan mengendalikan berpikir yang pada akhirnya akan menghasilkan kemampuan daklam berpikir kritis (Critical Thinking). Indikator-indikator keterampilan metakognisi menurut (Anatahime, 2007, p.1) yang akan dikembangkan antara lain mengidentifikasi tugas yang sedang dikerjakan, mengawasi dan mengevaluasi kemajuan pekerjaannya sehingga dapat memprediksi hasil yang akan diperoleh. keterampilan metakognisi ini dapat digunakan untuk mengasah keterampilan berpikir.

Peran guru sangat penting dalam meningkatkan metakognisi siswa. Guru dapat bertindak sebagai fasilitator yang memberikan bimbingan, mengarahkan langkah langkah dengan meginformasikan kemampuan dasar apa saja untuk menyelesaikan soal- soal tersebut sehingga siswa dapat menemukan solusi yang tepat dalam menyelesaikan masalah terutama soal-soal yang menuntut siswa berpikir kritis dan kreatig (Higher Order Thinking). 
Dengan melatih kognisi siswa keyakianan diri siwa dalam mengerjakan tugas-tugas (efikasi diri) dalam pembelajaran matematika akan terus meningkat. Individu yang memiliki efikasi diri yang tinggi ditandai dengan: memiliki pandangan positif tentang tugas yang dihadapi dan kayakinan bahwa dirinya mampu melakukan suatu tugas atau pekerjaan tertentu, memiliki dorongan yang kuat untuk berhasil mengerjakan tugas yang menjadi tanggung jawabnya, dan berusaha mencari jalan yang efektif untuk berhasil menyelesaikan tugasnya.

\section{KESIMPULAN}

Efikasi diri dalam pembelajaran matematika merupakan keyakinan seseorang mengenai kemampuannya dalam dalam mengerjakan tugas tugas yang diberikan oleh guru. salah satu Strategi yang dapat dilakukan untuk meningkatkan efikasi diri siswa adalah metakognisi. Metakognisi merupakan kesadaran dan pengetahuan berpikir seseorang dalam membangun strategi berpikir untuk memecahkan masalah.

Mengembangkan metakognisi pada dasarnya adalah meningkatkan proses berpikir seseorang untuk mengontrol apa yang dipikirkannya, apa yang dikerjakannya dengan tugas yang diberikan, apakah telah memenuhi tuntutan yang diminta dari tugas-tugas yang diberikan atau belum. Strategi. dengan meningkatkan kesadaran berpikir siswa maka siswa dapat mengorganisir pikirannya dengan merancang langkah-langkah apa saja yang bisa ia lakukan terutama dalam memilih rumus dan formula matematika untuk menyelesaikan tugas-tugas yang di berikan sehingga penggunaan konsep matematika dalam menyelesaikan masalah sangat tepat. dengan demikian, keyakianan diri siwa dalam mengerjakan tugas-tugas (efikasi diri) akan terus meningkat.

Individu yang memiliki efikasi diri yang tinggi ditandai dengan: memiliki pandangan positif tentang tugas yang dihadapi dan kayakinan bahwa dirinya mampu melakukan suatu tugas atau pekerjaan tertentu, memiliki dorongan yang kuat untuk berhasil mengerjakan tugas yang menjadi tanggung jawabnya, dan berusaha mencari solusi yang tepat dalam menyelesaikan tugasnya.

\section{DAFTAR PUSTAKA}

Albert Bandura. (1986). Social Foundation of thought and action: A Social Cognitif Theory New Jersey, Prentice-Hall,

Albert Bandura. (1997). Self-efficacy: The Exercise of Control. New York: W.H. Freeman.

Anatahime. 2007. Keterampilan Metakognitif. Diunduh pada tanggal 31 Juli 2021 dari http://biologyeducationresearch.blogspot.com/2009/12/keterampilanmetakognitif.html.

Arrend, I.R. (2007). Learning To Teach Sevend Edition, New York: McGraw Hill Companies. Bandura, A. (1997). Self Efficacy: The Exercise of Control. New York. Freeman.

Brunning, R.H., Schraw, GJ., \& Ronning, R,R. (1995) .Cognitive Psychology and Intruction, Second Edition, New Jersey : Prentice Hall.

DEPDIKNAS . (2003). Standar Kompetensi Matematika Kurikulum 2004

Ellis Ormrod, Jeanne. (2008). Psikologi Pendidikan:Membantu Siswa Tumbuh dan Berkembang. Jakarta : Erlangga.

Fisher, A. (2008). Berpikir Kritis : Sebuah Pengantar. Jakarta: Erlangga.

M. Nur Ghufron dan Rini Risnawita Sumint. (2016). Efikasi diri dan Hasil Belajar Matematika: Meta Analisis. Buletin Psikologi, 21(1)

Misel, E.S. (2016). Penerapan Pendekatan Matematika Realistik Untuk Meningkatakan Kemampuan Representasi Matematis Siswa. Didaktik. 10 (2), 27-36

Soedjadi. (2000). "Dalam Majalah Ilmiah Himpunan Matematika Indonesia". (Prosiding Konperensi Nasional Matematika X ITB, 17-20 Juli 2000)

Thayeb T., \& Putri, A. P. (2017). Kemampuan Metakognisi Untuk Meningkatakan Keterampilan Pemecahan Masalah Matematika Siswa Kelas VIII B MTS MADANI 
ALAUDDIN Paopao Kabupaten Gowa. Mapan : Jurnal Matematika dan Pembelajaran, p-ISSN: 2354-6883 ; e-ISSN: 2581-172X Volume 5, Nomor

P. Arifin, B. N. Trisna, and M. F. Atsnan, "Mengembangkan Self-Efficacy Matematika Melalui Pembelajaran Pendekatan Matematika Realistik Pada Siswa Kelas Vii D Smp Negeri 27 Banjarmasin Tahun Pelajaran 2016-2017”. vol. 3, no. 2, pp. 93-104, 2017.

U. Sholihah, "Membangun metakognisi siswa dalam memecahkan masalah matematika". vol. 04, no. 46, pp. 83-100. 